\title{
Antibacterial Sensitivities of Urinary Pathogenes among Children with Sickle Cell Anaemia in a Tertiary Hospital
}

\author{
Yauba $\mathrm{MS}^{1}$, Musa $\mathrm{A}^{1}$, Ibrahim $\mathrm{MS}^{2}$, Ibrahim $\mathrm{A}^{3}$, Aikhionbare $\mathrm{HA}^{1}$ \\ ${ }^{1}$ (Department of Paediatrics, Ahmadu Bello University Teaching Hospital, Zaria, Nigeria) \\ 2 (Department of Community Medicine, Ahmadu Bello University Teaching Hospital, Zaria, Nigeria) \\ ${ }^{3}$ (Department of Microbiology, Ahmadu Bello University Teaching Hospital, Zaria, Nigeria)
}

\begin{abstract}
Background: Urinary tract infection (UTI) is one of the major causes of morbidity and mortality in children especially among those with sickle cell anaemia (SCA).

Objectives: This study aimed to determine the aetiologic agents causing UTI and their antimicrobial sensitivity patterns among children with SCA in a tertiary hospital.

Methodology: Two hundred and seventy two children with SCA in stable state and in crises aged 6 months to 15 years had their urine samples screened for significant bacteriuria. The urine samples were collected aseptically and incubated aerobically at $37^{\circ} \mathrm{C}$ for 24 hours within one hour of collection for bacteriuria. Their antimicrobial sensitivity pattern was also determined.

Results:Bacterial isolates was detected in 22 (8.1\%) of the 272 subjects with SCA and occurred more in boys than in girls. The bacterial isolates were higher among those in crisis than among thosein steady state and the difference was statistically significant. The most common organisms isolates was Escherichia coli while the least isolated were salmonella typhi. Most organisms were resistance to the commonly used antibiotics.
\end{abstract}

Conclusion: Most commonlyurinary pathogens isolated were resistance to commonly used antibiotics.

Keywords: Antibacterial sensitivities, Children, Sickle Cell Anaemia, Urinary bacterial isolates

\section{Introduction}

Sickle cell anaemiain children is one of the predisposing factors to UTI due to the impaired immunological state like deficiency in serum opsonins and defective phagocytosis. ${ }^{1,2}$ Children with SCA have increased susceptibility to develop recurrent UTI and subsequent renal damage and chronic kidney disease (CKD). ${ }^{3}$ This is because of altered blood flow in the renal vasculature which causes papillary necrosis and loss of urinary concentrating and acidifying ability of the nephrons with the consequent formation of abnormally dilute and alkaline urine which favours bacterial proliferation. ${ }^{3}$ It is important,therefore, to regularly monitor the pattern of the organisms implicated inUTIand determine their antibiotic sensitivitiesamong SCA children to limit the development of CKD in this high-risk group of children. This present study was undertaken to determine the organisms causing UTI and their antibacterial sensitivity pattern among children with SCA in a Tertiaryhospital. The knowledge of antimicrobial sensitivities of the organisms causing UTI in SCA children may reduce the morbidity and mortality from CKD.

\section{Materials And Methods}

The study was conducted at the Department of Paediatrics, Ahmadu Bello University Teaching Hospital (ABUTH), Zaria, over a period of six months. The study was a prospective, descriptive and crosssectional one. The sample population consisted of consecutively selected children with SCA (in steady state and in crisis) aged 6 months to 15 years. Children with SCA who had been on antibiotics one week preceding enrolment into the study, those with confirmed (or suspected) congenital urogenital anomalies and those who had recent $(<1$ week) manipulative urogenital procedure (like catheterization and cystoscopy) were excluded from the study. Those whose parents or guardians did not consent and those with $\mathrm{HbSC}$ and other forms of sickle cell disease other than SCA were also excluded. Ethical approval was obtained from the ABUTH Research Committee and a written consent obtained from/ guardians of subjects. Age, sex and other sociodemographic characteristics were recorded in the study.

The urine samples were collected aseptically using standard techniques ${ }^{5}$ and incubated aerobically at $37^{\circ} \mathrm{C}$ for 24 hours within one hour of collection. Children whose urine samples yielded $\geq 10^{5} \mathrm{cfu} / \mathrm{ml}$ of bacteria on two consecutive cultures were regarded as having significant bacteriuria. Mixed growths of more than two species in a single urine sample were regarded as contaminants and therefore disregarded. Second urine samples were collected from children with significant bacteriuria and those whose second urine samples yielded $\geq 10^{5} \mathrm{cfu} /$ $\mathrm{ml}$ of bacteria were regarded as having significant bacteriuria. Organisms were identified using standard identification techniques. ${ }^{6}$ Antibiotic sensitivity test was also determined using standard methods. ${ }^{7}$ 


\section{Data analysis}

Data was analyzed using Epi Info version 3.5.3 statistical software. Values were expressed as frequency, mean and standard deviation. Chi-square test was used to determine the level of significance. P-values less than 0.05 were considered significant.

\section{Results \\ IV.1. SOCIODEMOGRAPHIC CHARACTERISTICS}

Two hundred and seventy two subjects with SCA, aged six (6) months to 15 years were analyzed with a mean age ( $\pm 1 \mathrm{SD})$ of $6.4 \pm 3.8$ years. Of these $185(68.0 \%)$ were in steady state and $87(32.0 \%)$ were in crisis. The mean age of SCA subjects in steady state was $6.8 \pm 3.9$ years while that of those in crisis was $5.6 \pm 3.7$ years. Thus they were not significantly different from each other. There were more males $(57.4 \%)$ than females $(42.6 \%)$ in the ratio of $1.3: 1$. There was no statistically significant difference in the distribution of sex within or between the two groups of children $(\mathrm{p}=0.96)$. The sex distribution in children in steady state was also not significantly different from that of children presenting in crises $\left(\chi^{2}=0.084, p=0.39\right)$. Table I showed the age and gender distribution of SCA subjects in crisis and in steady state

Table I: Age and gender distribution of SCA subjects in crisis and in steady state

\begin{tabular}{|c|c|c|c|c|c|}
\hline \multirow[b]{2}{*}{ Ages (Years) } & \multicolumn{2}{|c|}{ In steady state, n (\%) } & \multicolumn{2}{|c|}{ In crisis, $\mathrm{n}(\%)$} & \multirow[b]{2}{*}{ Total } \\
\hline & Male & Female & Male & Female & \\
\hline$<5$ & $35(33.3)$ & $27(33.8)$ & $26(51.0)$ & $18(50.0)$ & $106(84.1)$ \\
\hline $5-9$ & $40(38.1)$ & $35(43.8)$ & $16(31.4)$ & $11(30.6)$ & $102(71.5)$ \\
\hline $10-15$ & $30(28.6)$ & $18(22.5)$ & $9(17.6)$ & 7 (19.4) & $64(44.3)$ \\
\hline TOTAL & $105(100.0)$ & $80(100.0)$ & $51(100.0)$ & $36(100.0)$ & $\begin{array}{l}272 \\
(100.0)\end{array}$ \\
\hline
\end{tabular}

$\chi^{2}=0.084, p=0.39$

\section{IV.2. BACTERIAL ISOLATES AND ANTIBACTERIAL SENSITIVITY PATTERN}

A total of 22 organisms were isolated from the 22 children with SCA. Bacterial isolates was detected in $22(8.1 \%)$ of the 272 subjects with SCA and occurred more in boys than in girls (M: F ratio of 1.3: 1). The bacterial isolates was higher, $18(20.7 \%)$, among those in crisis than among those, $4(2.2 \%)$, in steady state and the difference was statistically significant $\left(\chi^{2}=27.323, \mathrm{p}=0.001\right)$. The most frequently isolated organisms were Escherichia coli $(11 ; 50.0 \%)$ followed by Klebsiellapneumoniae $(5 ; 22.7 \%)$. The least common isolates were Staphylococcus aureus $(2 ; 9.1 \%)$ and Salmonella typhi(1; 4.6\%; see Table II). Their antimicrobial sensitivities revealed that most organisms were sensitive to gentamycin, ciprofloxacin and ceftriaxone to which they demonstrated $95.5 \%, 100 \%$, and $100 \%$ sensitivity respectively. The isolates were least sensitive to the commonly used drugs including ampicillin, cotrimoxazole and amoxicillin to which they demonstrated $9.1 \%$, $13.6 \%$ and $18.2 \%$ sensitivities respectively. Table II showed the urinary bacterial isolates and their antibacterial sensitivity pattern.

Table II: Pathogens isolated from SCA subjects with significant bacteriuria and their antibiotics sensitivity pattern.

\begin{tabular}{|c|c|c|c|c|c|c|c|c|c|c|c|c|}
\hline \multicolumn{13}{|c|}{ Antibiotics sensitivity pattern, $\mathrm{n}(\%)$} \\
\hline Pathogens & No & CTM & GEN & AMOX & NFN & AUG & CEFT & CEFU & $\mathrm{CPH}$ & CIP & NA & AMPI \\
\hline E. coli & 11 & $2(18.2)$ & $11(100)$ & $1(9.1)$ & $9(81.8)$ & $3(27.3)$ & $11(100)$ & $7(63.6)$ & $2(18.2)$ & $11(100)$ & $6(54.5)$ & $1(9.1)$ \\
\hline Klebs & 5 & $1(20.0)$ & $5(100)$ & $1(20.0)$ & $3(60.0)$ & $1(20.0)$ & $5(100)$ & $4(80.0)$ & $2(40.0)$ & $5(40.0)$ & $3(60.0)$ & 0 \\
\hline Proteus & 3 & 0 & $3(100)$ & $0(0.0)$ & $1(33.3)$ & $3(100)$ & $3(100)$ & $3(100.0)$ & 0 & $3(100)$ & $2(66.7)$ & $1(33.3)$ \\
\hline Staph. $a$ & 2 & 0 & $1(50.0)$ & $2(100)$ & $1(50.0)$ & $2(100)$ & $2(100)$ & $2(100.0)$ & $1(50.0)$ & $2(100)$ & 0 & 0 \\
\hline Salmon & 1 & 0 & $1(100)$ & 0 & $1(100)$ & $1(100)$ & $1(100)$ & 0 & 0 & $1(100)$ & $1(100)$ & 0 \\
\hline TOTAL & 22 & $3(13.6)$ & $21(95.5)$ & $4(18.2)$ & $15(68.2)$ & $10(45.5)$ & $22(100)$ & $16(72.7)$ & $5(22.7)$ & $22(100)$ & $12(54.5)$ & $2(9.1)$ \\
\hline
\end{tabular}

$\mathrm{CTM}=$ Cotrimoxazole, $\mathrm{GEN}=$ Gentamycin, $\mathrm{AMOX}=$ Amoxicillin, $\mathrm{NFN}=$ Nitrofurantoin, $\mathrm{AUG}=$ Augmentin , $\mathrm{CEFT}=$ Ceftriaxone, $\mathrm{CEFU}=$ Cefuroxime, $\mathrm{CPH}=$ Cephalexin, $\mathrm{CIP}=$ Ciprofloxacin, NA $=$ Nalidixic acid, AMPI = Ampicillin. 


\section{Discussion}

Sickle cell anaemia children are prone UTI due to their impaired immunity and this may lead to chronic and end stage renal disease later in life. Studies on urinary bacterial isolates in children with SCA in this environment are very scanty. The finding of more bacterial isolates in children with SCA crisis than in those in steady state could suggest that UTI is an important contributor to the incidence of crises in children with SCA as was also documented by Maharaja atal. ${ }^{4}$ However, the lower bacterial isolates $(2.2 \%)$ obtained in steady state SCA subjects in this study was lower than the $6 \%$ prevalence obtained by Chukwuetal ${ }^{5}$ inEnugu and the $5.8 \%$ reported by Ajasin and Adegbola ${ }^{6}$ in Lagos in a similar population. The lower prevalence observed in this study as compared to those of Chukwuetal ${ }^{5}$ and Ajasin and Adegbola ${ }^{6}$ may be due to the difference in diagnostic criteria used in diagnosing UTI.

The finding that Escherichiacoliwas the most frequently isolated organisms followed by Klebsiellaspp in this study was similar to that of other studies. ${ }^{7,8}$ This may be due to the presence of bacterial pili or fimbrae, $\mathrm{K}$ antigens and $f y u \mathrm{~A}$ (yersiniabactin receptor) on the surface of the bacteria which render the bacteria more difficult tobephagocytosed and more resistant to the action of complement. The inability of the SCA subjects to concentrate and acidify urine leading to abnormally dilute and alkaline urine could also promote the growth of E. coli. ${ }^{9}$ Salmonellatyphi and Staphylococcusaureus were the organisms least isolated in this study. This finding is similar to that reported by others. ${ }^{9,12}$ The rarity of Salmonella UTI in these studies may be explained by the fact that Salmonella species are rare cause of UTI in children and bacteriuria from Salmonella is frequently associated with structural abnormalities of the urinary tract. ${ }^{10}$

This study revealed that most of the pathogens isolated were resistant to cotrimoxazole, ampicillin, cephalexin and amoxicillin similar to the findings reported by other studies. ${ }^{11,12}$ In a study in Saudi Arabia, it was reported that EscherihiacoliandKlebsiellawere highly susceptible to cotrimoxazole. ${ }^{13}$ The reason for the contrast may be that cotrimoxazoleis not a common on- the- counter drug in Saudi Arabia;meanwhile, it is very common in Nigeria. Thus, resistanceeasily develops.

This study revealed that ceftriaxone, ciprofloxacin, gentamycin, cefuroxime and nitrofurantoin were the antibiotics to which most of the bacterial isolates were sensitive. These findings were similar to those reported by others. ${ }^{14,15}$ The explanation for this high sensitivity of this urinary isolates to this drugs in this study may be due to the fact that, in this environment, most parents cannot afford this drug even when prescribed and this may lead to low drug pressure and high sensitivity.

\section{Conclusion}

Overall, bacterial isolates were found to be more among SCA children in crises than among those in steady state. Escherichia coli followed by Klebsiellaspp were the commonest pathogens isolated. There was a high degree of resistance of isolated urinary organisms to commonly used antibiotics. It is recommended that routine urine screening for UTI and their antimicrobial sensitivities be carried out in children, particularly under-fives, presenting to our hospitals with SCA crisis. Cefuroxime and nitrofurantoin should be recommended as first line drugs for treatment of simple UTI while awaiting results of urine culture and sensitivity.

\section{Acknowledgements}

We wish to acknowledge Professor Ogunrende GO and DrBugaje MA all of the department of paediatrics of ABUTH, Zaria for their supervisory role of this work as well as Dr. Shamsu of the department of microbiology of ABUTH for assisting in the laboratory aspect of this study.

\section{References}

[1]. Kizito ME, Mworozi E, Ndugwa C, Serjeant GR. Bacteraemia in homozygous sickle cell disease in Africa: Is pneumococcal prophylaxis justified? Arch Dis Child 2007;92:21-3.

[2]. Anna NW, Jerry AW, Andrea J, Howard ML. Serum opsonic activity in infant with sickle cell disease immunized with pneumococcal polysaccharide protein conjugate vaccine. ClinDiag Lab Immunol 2000; 7: 788-793.

[3]. Smith CH: Blood diseases of infancy and childhood. St. Louis: C. V. Mosby Company;, 3 1972, 376-377.

[4]. Maharaja R, Fleming AF, Egler LJ. Pattern of infections among patients with sickle cell anaemia requiring hospital admissions. Nig J Paediatr 1983; 10: $13-17$.

[5]. Chukwu BF, Okafor HU, Ikefuna AN. Socio-demographic factors associated with asymptomatic bacteriuria in children with sickle cell anemia in a tertiary health facility in South eastern, Nigeria. Italian J Pediatr. 2011; 3: 1-5.

[6]. Ajasin MA, Adegbola RA. Asymptomatic bacteriuria in children with sickle cell anaemia. Nig J Paediatr 1988; 15: 19-25.

[7]. Aladekomo TA, Oyelami OA, Oyedeji GA, Akinsola A. Symptomatic bacteriuria in South Western Nigerian primary school pupils. Intern J Trop Med 2008; 3: 1-4.

[8]. Owa JA. Urinary Tract Infections in Children. In: Azubuike JC, Nkanginieme KEO. Paediatrics and Childhealth in a Tropical Region. Second edn. African Educational Service: Owerri, 2007: 480-487.

[9]. Asinobi AO, Fatunde OJ, Brown BJ, Osinusi K, Fasina NA. Urinary tract infection in febrile children with sickle cell anaemia in Ibadan, Nigeria. Ann Trop. Paediatr 2003; 23: 129-134.

[10]. Akuse RM. The Pattern of Bacterial Infection and Intercurrent Morbidity in Sickle Cell Disease Patients. A Dissertation Submitted to the National Postgraduate Medical College of Nigeria in Part Fulfillment of the Requirements for the Fellowship of the College 1990: 318-323. 
[11]. Adeyemo AA, Gbadegesin RA, Onyemenem TN, Ekweozor CC. Urinary tract pathogens and antimicrobial sensitivity patterns in children in Ibadan, Nigeria. Ann Trop Paediatr 1994; 14: 271- 4.

[12]. Obaseiki- Ebor EE. Trimethoprim / sulphamethoxazole resistance in E. coli and Klebsiellaspp urinary isolates. Afr J Med Sci 1988;17:133- 40.

[13]. Elbashier AM, Badu GA. Pattern of bacteriuria in patients with sickle cell disease in Qatif Central Hospital. Saudi Med J 1991;12:121- 4 .

[14]. Brown BJ, Asinobi AO, Fatunde OJ, Osinusi K, Fasina NA. Antimicrobial sensitivity pattern of organisms causing urinary tract infection in children with sickle cell anaemia in Ibadan, Nigeria. W Afr J Med 2003; 22: 110-113.

[15]. Mava Y, Bello M, Ambe JP, Zailani SB. Antimicrobial sensitivity pattern of organisms causing urinary tract infection in children with sickle cell anemia in Maiduguri, Nigeria.Nig J ClinPract2012; 15: 420-23. 